\title{
Article
}

\section{Biomarkers for Lifetime Caries-Free Status}

\author{
Ariana M. Kelly, Mariana Bezamat $(\mathbb{D}$, Adriana Modesto and Alexandre R. Vieira *D
}

School of Dental Medicine, University of Pittsburgh, Pittsburgh, PA 15260, USA; amk211@pitt.edu (A.M.K.); mbl29@pitt.edu (M.B.); ams208@pitt.edu (A.M.)

* Correspondence: arv11@pitt.edu; Tel.: +1-412-383-8972

\section{check for}

updates

Citation: Kelly, A.M.; Bezamat, M.; Modesto, A.; Vieira, A.R. Biomarkers for Lifetime Caries-Free Status. J. Pers. Med. 2021, 11, 23. https://doi.org/ 10.3390/jpm11010023

Received: 26 November 2020 Accepted: 28 December 2020 Published: 30 December 2020

Publisher's Note: MDPI stays neutral with regard to jurisdictional clai$\mathrm{ms}$ in published maps and institutional affiliations.

Copyright: $\odot 2020$ by the authors. Licensee MDPI, Basel, Switzerland. This article is an open access article distributed under the terms and conditions of the Creative Commons Attribution (CC BY) license (https:// creativecommons.org/licenses/by/ $4.0 /)$.

\begin{abstract}
The purpose of this study was to address the hypothesis that extreme outcomes of dental caries, such as edentulism or prematurely losing permanent teeth are associated with genetic variation in enamel-formation genes. After scanning 6206 individuals, samples of 330 were selected for this study. Tested phenotypes included patients who were edentulous by age 30, patients with missing first molars by age 30, patients with missing second molars by age 30 , and caries-free patients. Fourteen single nucleotide polymorphisms were genotyped by TaqMan chemistry. The analyses of each phenotype were performed using the software PLINK with an alpha of 0.05 . Nominal associations were found between rs12640848 in enamelin $(p=0.05)$, rs1784418 in matrix metallopeptidase 20 $(p=0.02)$, and rs5997096 in the tuftelin interacting protein 11 and being caries-free at the age of 60. When combining patients that were missing both first mandibular molars and missing both second mandibular molars, no associations were found. Matrix metallopeptidase 20, and tuftelin interacting protein 11 also showed trends for association with being caries-free. Genetic variation in TFIP11, $M M P 20$, and ENAM may have a protective effect increasing the chances of individuals preserving their teeth caries-free over a lifetime.
\end{abstract}

Keywords: dental caries; edentulism; genomics

\section{Introduction}

Dental caries is second only to influenza in the number of people it affects around the globe [1]. For more than 100 years, we have defined how its pathogenesis works. However, that knowledge did not allow for a total eradication of this highly preventable disease. Interventions for dental caries, aside from fluoridating the drinking water or application of sealants in school children, have been limited. Furthermore, the practice of fluoridating the drinking water will soon be challenged since there is evidence that prenatal exposure may impact cognitive performance [2].

The current challenge with dental caries is identifying individuals that are at higher risk of the disease. These individuals, who are approximately $25 \%$ of the total number of individuals affected, have $80 \%$ of the disease burden [3]. Since it is unrealistic to expect that interventions that can impact sugar consumption, such as taxation of sugar products, will be implemented relatively soon [4], and dentists are not trained to effectively implement behavioral-change interventions [5], the identification of markers that help identify individuals at higher risk are needed.

The focus on the host is potentially a strategy that may benefit the fight against dental caries. There is unquestionable evidence that dental caries has a genetic component, and genes associated with dental caries include the ones involved in mineralization of bone, formation of enamel, microbial colonization, and the degradation of amelogenin [6-8]. These studies so far included the typical dental patients that are found to have carious lesions, and the definition of the phenotype range from unsophisticated analyses of individuals with no lesions versus any number of lesions [9], self-reported tooth loss [10], individuals with no lesions versus ones with a substantial number of lesions [11], to a more sophisticated framework taking into consideration the number of lesions and the age 
of the individuals [12]. Likewise, our recent study demonstrated a potential genetic component present in cancer-diagnosed individuals who had tooth loss/edentulism [13]. However, the main limitation experienced was the lack of phenotype differentiation between losing one tooth or being edentulous. Here we hypothesized that creating definitions that clearly select individuals more severely affected will provide us with a chance to identify genetic markers that may serve as risk discriminators. Therefore, the purpose of this study was to test extreme outcomes of dental caries, such as edentulism at young age or prematurely losing permanent mandibular molars, to determine genetic biomarkers that can be used at the population level to identify individuals at higher risk for dental caries.

\section{Materials and Methods}

Beginning in September 2006, every individual that comes to the University of Pittsburgh School of Dental Medicine for treatment has been given the opportunity to be a part of the Dental Registry and DNA Repository project (University of Pittsburgh Institutional Review Board (IRB) approval \# 0606091). This study conforms to the STROBE (Strengthening the Reporting of Observational Studies in Epidemiology) guidelines [14]. At the time of this analysis, there were 6206 subjects in the University of Pittsburgh School of Dental Medicine Dental Registry and DNA Repository project $[5,15]$. All individuals who agreed to participate gave written, informed consent authorizing the use of information from their dental and medical records. From the total of 6206 individuals participating in the registry, the records of 330 were obtained to perform the present study. The tested phenotypes included edentulous patients by age 30 , patients with missing first molars by age 30 , patients with missing second molars by age 30, and caries-free patients (Table 1). Missing teeth in all groups were due to dental caries. Individuals with missing teeth due to reasons other than dental caries were not included in the study.

Table 1. Sex and ethnicity of individuals selected for the study by their phenotypic groups.

\begin{tabular}{ccccccc}
\hline \multirow{2}{*}{ Phenotype } & N & \multicolumn{3}{c}{ Sex } & \multicolumn{3}{c}{ Ethnicity * } \\
\cline { 3 - 7 } & & Female & Male & White & Black & Other \\
\hline Edentulous by Age 30 & 30 & 12 & 18 & 30 & 0 & 0 \\
\hline $\begin{array}{c}\text { Missing mandibular first molars } \\
\text { by age 30 }\end{array}$ & 267 & 136 & 131 & 188 & 70 & 9 \\
\hline $\begin{array}{c}\text { Missing mandibular second } \\
\text { molars by age 30 }\end{array}$ & 180 & 98 & 82 & 130 & 45 & 5 \\
\hline Caries-free & 161 & 87 & 74 & 127 & 31 & 3 \\
\hline
\end{tabular}

${ }^{*}$ Note: White indicated self-reported European descent, Black indicated self-reported African American, and Other
included self-reported Asians and American Indians.

Genomic DNA was extracted from salivary samples of the 330 individuals for the genetic analyses proposed for this study. Fourteen single nucleotide polymorphisms (ESRRB rs10132091 and rs6574293, Defensin rs11362, ENAM rs12640848, MMP20 rs1784418, KLK4 rs198968 and rs2235091, ALOX15 rs2619112 and rs7217186, PART1 rs27565, AQP5 rs3736309, Tuftelin 1 rs3790506, and AMBN rs4694075 and SRRD/TFIP11 rs5997096) previously associated with dental caries in our studies [6,11,16-25] were genotyped using TaqMan chemistry (Applied Biosystems) [26]. The analyses of each phenotype, using sex and ethnicity as covariates were performed using the software PLINK (Center for Human Genetic Research (CHGR), Massachusetts General Hospital (MGH), and the Broad Institute of Harvard and MIT) [27]. The software generated the frequency of a particular variant in cases versus controls. An alpha of 0.05 was considered for nominal results and a Bonferroni correction was applied for multiple testing and $p$-values below $0.003(0.05 / 14)$ were considered significant. This more stringent value aimed to retain the prescribed family-wise error rate alpha. The caries-free individuals served as reference (Table 3). 
Table 2. Genotyping distribution per tested phenotype.

\begin{tabular}{|c|c|c|c|c|c|c|c|c|}
\hline \multirow{2}{*}{ Phenotype } & \multirow[b]{2}{*}{ SNP } & \multicolumn{3}{|c|}{ Affected } & \multicolumn{3}{|c|}{ Caries-Free at Age 60} & \multirow[b]{2}{*}{$p$-Value } \\
\hline & & $\mathbf{A A}^{*}$ & AB & BB & AA & AB & BB & \\
\hline \multirow{14}{*}{$\begin{array}{l}\text { Edentulous by } \\
\text { age } 30\end{array}$} & rs3790506 & 4 & 11 & 9 & 6 & 25 & 35 & 0.35 \\
\hline & rs4694075 & 6 & 14 & 7 & 17 & 27 & 21 & 0.66 \\
\hline & rs12640848 & 7 & 7 & 16 & 22 & 28 & 25 & 0.15 \\
\hline & rs27565 & 5 & 11 & 5 & 15 & 23 & 25 & 0.35 \\
\hline & rs11362 & 6 & 12 & 8 & 19 & 27 & 22 & 0.83 \\
\hline & rs1784418 & 7 & 16 & 6 & 6 & 46 & 22 & 0.08 \\
\hline & rs3736309 & 2 & 12 & 16 & 4 & 15 & 53 & 0.12 \\
\hline & rs6574293 & 0 & 4 & 21 & 2 & 11 & 56 & 0.69 \\
\hline & rs10132091 & 5 & 10 & 9 & 13 & 36 & 20 & 0.65 \\
\hline & rs2619112 & 4 & 10 & 13 & 13 & 36 & 22 & 0.28 \\
\hline & rs7217186 & 3 & 11 & 9 & 16 & 37 & 15 & 0.23 \\
\hline & rs2235091 & 1 & 7 & 10 & 8 & 24 & 25 & 0.53 \\
\hline & rs198968 & 8 & 9 & 12 & 14 & 18 & 41 & 0.39 \\
\hline & rs5997096 & 0 & 5 & 16 & 2 & 14 & 47 & 0.71 \\
\hline \multirow{14}{*}{$\begin{array}{c}\text { Missing } \\
\text { mandibular } \\
\text { first molars by } \\
\text { age } 30\end{array}$} & rs3790506 & 16 & 47 & 111 & 6 & 25 & 35 & 0.25 \\
\hline & rs4694075 & 42 & 89 & 48 & 17 & 27 & 21 & 0.52 \\
\hline & rs12640848 & 68 & 51 & 75 & 22 & 28 & 25 & 0.17 \\
\hline & rs27565 & 34 & 68 & 59 & 15 & 23 & 25 & 0.73 \\
\hline & rs11362 & 40 & 72 & 58 & 19 & 27 & 22 & 0.78 \\
\hline & rs1784418 & 17 & 118 & 60 & 6 & 46 & 22 & 0.97 \\
\hline & rs3736309 & 8 & 49 & 142 & 4 & 15 & 53 & 0.73 \\
\hline & rs6574293 & 4 & 34 & 142 & 2 & 11 & 56 & 0.83 \\
\hline & rs10132091 & 35 & 86 & 62 & 13 & 36 & 20 & 0.72 \\
\hline & rs2619112 & 36 & 105 & 49 & 13 & 36 & 22 & 0.7 \\
\hline & rs7217186 & 48 & 78 & 57 & 16 & 37 & 15 & 0.26 \\
\hline & rs2235091 & 14 & 51 & 59 & 8 & 24 & 25 & 0.83 \\
\hline & rs198968 & 45 & 31 & 111 & 14 & 18 & 41 & 0.29 \\
\hline & rs5997096 & 1 & 50 & 108 & 2 & 14 & 47 & 0.15 \\
\hline \multirow{10}{*}{$\begin{array}{c}\text { Missing } \\
\text { mandibular } \\
\text { second molars } \\
\text { by age } 30\end{array}$} & rs3790506 & 12 & 35 & 81 & 6 & 25 & 35 & 0.31 \\
\hline & rs4694075 & 32 & 62 & 34 & 17 & 27 & 21 & 0.62 \\
\hline & rs12640848 & 54 & 34 & 55 & 22 & 28 & 25 & 0.1 \\
\hline & rs27565 & 31 & 50 & 39 & 15 & 23 & 25 & 0.62 \\
\hline & rs11362 & 35 & 54 & 35 & 19 & 27 & 22 & 0.82 \\
\hline & rs1784418 & 12 & 84 & 46 & 6 & 46 & 22 & 0.91 \\
\hline & rs3736309 & 7 & 35 & 105 & 4 & 15 & 53 & 0.87 \\
\hline & rs6574293 & 4 & 21 & 106 & 2 & 11 & 56 & 1 \\
\hline & rs10132091 & 29 & 62 & 42 & 13 & 36 & 20 & 0.75 \\
\hline & rs2619112 & 21 & 80 & 37 & 13 & 36 & 22 & 0.6 \\
\hline
\end{tabular}

${ }^{*}$ Note: AA and BB indicate each homozygotes state, and AB indicates the heterozygous state. 
Table 3. Genotyping distribution per tested phenotype.

\begin{tabular}{|c|c|c|c|c|c|c|c|c|}
\hline \multirow[b]{2}{*}{ Phenotype } & \multirow[b]{2}{*}{ SNP } & \multicolumn{3}{|c|}{ Affected } & \multicolumn{3}{|c|}{ Caries-Free at Age 60} & \multirow[b]{2}{*}{$p$-Value } \\
\hline & & $\mathbf{A A}^{*}$ & AB & BB & AA & $\mathrm{AB}$ & BB & \\
\hline & rs7217186 & 33 & 60 & 38 & 16 & 37 & 15 & 0.46 \\
\hline & rs2235091 & 10 & 36 & 39 & 8 & 24 & 25 & 0.92 \\
\hline & rs198968 & 30 & 29 & 79 & 14 & 18 & 41 & 0.8 \\
\hline & rs5997096 & 0 & 39 & 76 & 2 & 14 & 47 & 0.03 \\
\hline
\end{tabular}

* Note: AA and BB indicate each homozygotes state, and AB indicates the heterozygous state.

\section{Results}

Genotyping distributions of TFIP11 rs5997096 in individuals who lost their second mandibular molars by age 30 was different from those of individuals who were caries-free by age $60(p=0.03)$, with caries-free individuals more likely to have one or two copies of the less common allele.

In the instances where genotyping distribution $p$-values were between 0.051 and 0.15 , we tested for dominant and recessive models. Nominal associations were found between ENAM rs12640848 and edentulism in the dominant model $(p=0.05)$, as well as MMP20 rs1784418 and edentulism in the recessive model $(p=0.02)$. Individuals caries-free by age 60 were more likely to have the less common allele of ENAM rs12640848 and two copies of the less common allele of MMP20 rs1784418. Considering just the loss of one permanent mandibular molar (first or second, left or right) did not change these results. The differences in sex and ethnicity did not appear to influence the results.

\section{Discussion}

This report is the first explicit attempt to define genomic biomarkers for dental caries, approaching the problem by testing individuals with extreme scenarios, such as having lost all their teeth by age 30 or lost the 6- and 12-year mandibular molars by age 30 , in contrast to a lifetime being caries-free. Looking at extremes of phenotypic presentations has been successfully used to study obesity [28], erosive tooth wear ex vivo [29], and dental caries experience $[11,30]$. We identified one genetic variant that has the potential to discriminate individuals who are at the lowest risk for losing teeth early in life and therefore remain caries-free for a lifetime, despite all odds.

The study of dental caries in humans has relied on phenotypical definitions that in many instances do not inform disease mechanisms but caries experience. Different from other conditions with higher heritability, the genetic variance that explains the burden of dental caries in populations is likely easily overcome by environmental factors. Therefore, comparing individuals who are caries-free with individuals with any number of lesions may limit the ability to identify biological components contributing to caries. Phenotypical definitions that rely on trajectories of disease [31] might be a more promising way to study the problem.

MMP20 is a matrix metalloproteinase that modifies amelogenin, the primary enamel matrix secreted protein during ameloblast maturation $[32,33]$. We and others $[23,34,35]$ showed earlier that the less-common allele of MMP20 rs1784418 appears to have a protective effect against caries experience and these results are supported by our most recent findings in extreme phenotypes.

Another interesting finding is the association of TFIP11 with being a lifetime cariesfree individual. We have shown associations between TFIP11 and formation of artificial caries subclinical lesions and speculated that this may be due to the influence of TFIP11 in the dental enamel ability to reuptake fluoride from the environment $[6,8]$. This early finding is compatible to our results suggesting that TFIP11 is associated with being caries-free.

Finally, ENAM rs12640848 was also associated with being caries-free over a lifetime. We previously showed that ENAM rs3796704 was associated with having a dental enamel 
that was softer [8]. Others have also shown missense mutations in ENAM linked to higher caries experience [36]. These data suggest that depending on the variant, enamelin can be either protective or can increase the susceptibility to dental caries.

Pittsburgh is the largest city adjacent to one of the poorest areas in the USA, Appalachia. The Appalachian mountain range extends across 13 states in the United States from New York to Mississippi. Socio-economic indicators are much worse for the communities in the Appalachian region compared to those in the rest of the United States [37]. In regard to health indicators, Pittsburgh reflects what is found in the Appalachian region, and the population treated at the University of Pittsburgh Medical Center has some of the worst health indicators in the country, which makes Pittsburgh a perfect laboratory for studying disease risks [38]. This may be particularly true for the study of dental caries. Since the disease has a heritability likely not much higher than $20 \%$, factors such as diet, type of bacterial colonization, and oral hygiene habits are very relevant. However, in our cohort, socioeconomics of the patients was not dramatically different, and quality of oral hygiene and diet may be less variable in a group that averages more than 15 affected teeth [38]. On the other hand, the distinct profile of the population surrounding Pittsburgh may be too unique to make our findings generalizable and it is desirable to repeat these experiments in other parts of the world.

Being concerned about multiple testing, we applied the strict Bonferroni correction and none of the associations reached the determined threshold of $p$-values below 0.003 . We have demonstrated before [39] that known true associations are missed when correction for multiple testing is implemented. The results of our work should be considered with caution and serve to generate hypotheses to be directly tested in larger and more homogeneous samples. At the same time, nominal associations found here should be considered as trends for associations and should not be ignored. Other perceived limitations of our study are the distribution of Blacks and Whites in some of the comparisons that may have been unequal, the relatively small group $(n=30)$ of edentulous individuals by age 30 , and the absence of a direct measure of oral hygiene and diet.

Strategies for identifying individuals at higher risk for dental caries are still needed. Clinical findings such as Class II malocclusion, open bite, and dental crowding showed trends for associating with lower caries experience in the primary dentition [40]. Genetic associations may only be unveiled under a common dysbiotic scenario following local or systemic changes [41-43], and this is challenging to measure.

\section{Conclusions}

In summary, genetic variation in TFIP11, MMP20, and ENAM may have a protective effect increasing the chances of individuals preserving their teeth caries-free over a lifetime. These results show that these genomic biomarkers may be useful to determine individual susceptibility to dental caries, which may have consequences for predicting poorer overall health later in life.

Author Contributions: Conceptualization, A.R.V.; methodology, A.R.V.; formal analysis, A.M.K., M.B., and A.R.V.; investigation, A.M.K., M.B., A.M., and A.R.V.; resources, A.M. and A.R.V.; data curation, A.M.K., M.B., and A.R.V.; writing-original draft preparation, A.R.V.; writing-review and editing, A.M.K., M.B., A.M., and A.R.V.; supervision, A.R.V.; project administration, A.R.V.; funding acquisition, A.M. and A.R.V. All authors have read and agreed to the published version of the manuscript.

Funding: The Dental Registry and DNA Repository project is funded by the University of Pittsburgh School of Dental Medicine.

Institutional Review Board Statement: The study was conducted according to the guidelines of the Declaration of Helsinki, and approved by the University of Pittsburgh Institutional Review Board (protocol code 0606091, 7/12/2005).

Informed Consent Statement: Informed consent was obtained from all subjects involved in the study.

Data Availability Statement: The data presented in this study are available upon request. 
Acknowledgments: Data reported here were obtained from the Dental Registry and DNA Repository project.

Conflicts of Interest: The authors declare no conflict of interest.

\section{References}

1. Edelstein, B.L. The dental caries pandemic and disparities problem. BMC Oral Health 2006, 6, S2. [CrossRef] [PubMed]

2. Green, R.; Lanphear, B.; Hornung, R.; Flora, D.; Martinez-Mier, E.A.; Neufeld, R.; Ayotte, P.; Muckle, G.; Till, C. Association between maternal fluoride exposure during pregnancy and IQ scores in offspring in Canada. JAMA Pediatr. 2019, 173, 940-948. [CrossRef] [PubMed]

3. Kaste, L.M.; Selwitz, R.H.; Oldakowski, R.J.; Brunelle, J.A.; Winn, D.M.; Brown, L.J. Coronal caries in the primary and permanent dentition of children and adolescents 1-17 years of age: United States, 1988-1991. J. Dent. Res. 1996, 75, 631-641. [CrossRef]

4. Lloyd, P.; MacLaren, D. Should We tax sugar and if so how? Aust. Econ. Rev. 2019, 52, 19-40. [CrossRef]

5. Amoo-Achampong, F.; Vitunac, D.E.; Deeley, K.; Modesto, A.; Vieira, A.R. Complex patterns of response to oral hygiene instructions: Longitudinal evaluation of periodontal patients. BMC Oral Health 2018, 18, 72. [CrossRef] [PubMed]

6. Shimizu, T.; Ho, B.; Deeley, K.; Briseño-Ruiz, J.; Faraco, I.M., Jr.; Schupack, B.I.; Brancher, J.A.; Pecharki, G.D.; Küchler, E.C.; Tannure, P.N.; et al. Enamel formation genes influence enamel microhardness before and after cariogenic challenge. PLoS ONE 2012, 7, e45022. [CrossRef] [PubMed]

7. Vieira, A.R.; Modesto, A.; Marazita, M.L. Caries: Review of human genetics research. Caries Res. 2014, 48, 491-506. [CrossRef] [PubMed]

8. Bayram, M.; Deeley, K.; Reis, M.F.; Trombetta, V.M.; Ruff, T.D.; Sencak, R.C.; Hummel, M.; Dizak, P.M.; Washam, K.; Romanos, H.F.; et al. Genetic influences on dental enamel that impact caries differ between the primary and permanent dentitions. Eur. J. Oral Sci. 2015, 123, 327-334. [CrossRef]

9. Shaffer, J.R.; Wang, X.; Feingold, E.; Lee, M.; Begum, F.; Weeks, D.E.; Cuenco, K.T.; Barmada, M.M.; Wendell, S.K.; Crosslin, D.R.; et al. Genome-wide association scan for childhood caries implicates novel genes. J. Dent. Res. 2011, 90, 1457-1462. [CrossRef]

10. Shungin, D.; Haworth, S.; Divaris, K.; Agler, C.S.; Kamatani, Y.; Lee, M.K.; Grinde, K.; Hindy, G.; Alaraudanjoki, V.; Pesonen, P.; et al. Genome-wide analysis of dental caries and periodontitis combining clinical and self-reported data. Nat. Commun. 2019, 10, 2773. [CrossRef]

11. Patir, A.; Seymen, F.; Yildirim, M.; Deeley, K.; Cooper, M.E.; Marazita, M.L.; Vieira, A.R. Enamel formation genes are associated with high caries experience in Turkish children. Caries Res. 2008, 42, 394-400. [CrossRef] [PubMed]

12. Vieira, A.R.; Marazita, M.; Goldstein-McHenry, T. Genome-wide scan finds suggestive caries loci. J. Dent. Res. 2008, 87, 435-439. [CrossRef] [PubMed]

13. Bezamat, M.; Harrison, B.; Zhou, Y.; Glickman, K.M.; Telles, V.; Guirguis, C.; Modesto, A.; Vieira, A.R. Phenome-wide scan finds potential orofacial risk markers for cancer. Sci. Rep. 2020, 10, 4869. [CrossRef] [PubMed]

14. Von Elm, E.; Altman, D.G.; Egger, M.; Pocock, S.J.; Gøtzsche, P.C.; Vandenbroucke, J.P. The strengthening the reporting of observational studies in epidemiology (STROBE) statement: Guidelines for reporting observational studies. J. Clin. Epidemiol. 2008, 61, 344-349. [CrossRef] [PubMed]

15. Vieira, A.R.; Silva, M.B.; Souza, K.K.A.; Filho, A.V.A.; Rosenblatt, A.; Modesto, A. A pragmatic study shows failure of dental composite fillings is genetically determined: A contribution to the discussion on dental amalgams. Front. Med. 2017, 4, 186. [CrossRef] [PubMed]

16. Deeley, K.; Letra, A.; Rose, E.K.; Brandon, C.A.; Resick, J.M.; Marazita, M.L.; Vieira, A.R. Possible association of amelogenin to high caries experience in a Guatemalan-Mayan population. Caries Res. 2008, 42, 8-13. [CrossRef] [PubMed]

17. Ozturk, A.; Famili, P.; Vieira, A.R. The antimicrobial peptide DEFB1 is associated with caries. J. Dent. Res. 2010, 89, 631-636. [CrossRef]

18. Shimizu, T.; Deeley, K.; Briseño-Ruiz, J.; Faraco, I.M., Jr.; Poletta, F.A.; Brancher, J.A.; Pecharki, G.D.; Küchler, E.C.; Tannure, P.N.; Lips, A.; et al. Fine-mapping of 5q12.1-13.3 unveils new genetic contributors to caries. Caries Res. 2013, 47, 273-283. [CrossRef]

19. Ergöz, N.; Seymen, F.; Gencay, K.; Tamay, Z.; Deeley, K.; Vinski, S.; Vieira, A.R. Genetic variation in ameloblastin is associated with caries in asthmatic children. Eur. Arch. Paediatr. Dent. 2014, 15, 211-216. [CrossRef]

20. Krasone, K.; Lace, B.; Akota, I.; Care, R.; Deeley, K.; Küchler, E.C.; Vieira, A.R. Genetic variation in the promoter region of beta-defensin 1 (DEFB 1) is associated with high caries experience in children born with cleft lip and palate. Acta Odontol. Scand. 2014, 72, 235-240. [CrossRef]

21. Weber, M.L.; Hsin, H.Y.; Kalay, E.; Brožková, D.S.; Shimizu, T.; Bayram, M.; Deeley, K.; Küchler, E.C.; Forella, J.; Ruff, T.D.; et al. Role of estrogen related receptor beta (ESRRB) in DFN35B hearing impairment and dental decay. BMC Med. Genet. 2014, 15, 81. [CrossRef]

22. Abbasoğlu, Z.; Tanboğa, I.; Küchler, E.C.; Deeley, K.; Weber, M.; Kaspar, C.; Korachi, M.; Vieira, A.R. Early childhood caries is associated with genetic variants in enamel formation and immune response genes. Caries Res. 2015, 49, 70-77. [CrossRef]

23. Anjomshoaa, I.; Briseño-Ruiz, J.; Deeley, K.; Poletta, F.A.; Mereb, J.C.; Leite, A.L.; Barreta, P.A.T.M.; Silva, T.L.; Dizak, P.; Ruff, T.; et al. Aquaporin 5 interacts with fluoride and possibly protects against caries. PLoS ONE 2015, 10, e0143068. [CrossRef] [PubMed]

24. Filho, A.V.; Calixto, M.S.; Deeley, K.; Santos, N.; Rosenblatt, A.; Vieira, A.R. MMP20 rs1784418 protects certain populations against caries. Caries Res. 2017, 51, 46-51. [CrossRef] 
25. Vieira, A.R.; Bayram, M.; Seymen, F.; Sencak, R.C.; Lippert, F.; Modesto, A. In vitro acid-mediated initial dental enamel loss is associated with genetic variants previously linked to caries experience. Front. Physiol. 2017, 8, 104. [CrossRef] [PubMed]

26. Ranade, K.; Chang, M.-S.; Ting, C.-T.; Pei, D.; Hsiao, C.-F.; Olivier, M.; Pesich, R.; Hebert, J.; Chen, Y.-D.I.; Dzau, V.J.; et al. High-throughput genotyping with single nucleotide polymorphisms. Genome Res. 2001, 11, 1262-1268.

27. Purcell, S.; Neale, B.; Todd-Brown, K.; Thomas, L.; Ferreira, M.A.R.; Bender, D.; Maller, J.; Sklar, P.; de Bakker, P.I.W.; Daly, M.J.; et al. PLINK: A tool set for whole-genome association and population-based linkage analyses. Am. J. Hum. Genet. 2007, 81, 559-575. [CrossRef]

28. Calton, M.A.; Ersoy, B.A.; Zhang, S.; Kane, J.P.; Malloy, M.J.; Pullinger, C.R.; Bromberg, Y.; Pennacchio, L.E.; Dent, R.; McPherson, R.; et al. Association of functionally significant Melanocortin-4 but not Melanocortin-3 receptor mutations with severe adult obesity in a large North American case-control study. Hum. Mol. Genet. 2008, 18, 1140-1147. [CrossRef] [PubMed]

29. Uhlen, M.M.; Stenhagen, K.R.; Dizak, P.M.; Holme, B.; Mulic, A.; Tveit, A.B.; Vieira, A.R. Genetic variation may explain why females are less susceptible to dental erosion. Eur. J. Oral Sci. 2016, 124, 426-432. [CrossRef] [PubMed]

30. Slayton, R.L.; Cooper, M.E.; Marazita, M.L. Tuftelin, mutans streptococci, and dental caries susceptibility. J. Dent. Res. 2005, 84, 711-714. [CrossRef]

31. Weber, M.; Søvik, J.B.; Mulic, A.; Deeley, K.; Tveit, A.B.; Forella, J.; Shirey, N.; Vieira, A.R. Redefining the phenotype of dental caries. Caries Res. 2018, 52, 263-271. [CrossRef] [PubMed]

32. Llano, E.; Pendás, A.M.; Knäuper, V.; Sorsa, T.; Salo, T.; Salido, E.; Murphy, G.; Simmer, J.P.; Bartlett, J.D.; López-Otín, C. Identification and structural and functional characterization of human enamelysin (MMP-20). Biochemistry 1997, 36, 15101-15108. [CrossRef] [PubMed]

33. Väänänen, A.; Tjäderhane, L.; Eklund, L.; Heljasvaara, R.; Pihlajaniemi, T.; Herva, R.; Ding, Y.; Bartlett, J.D.; Salo, T. Expression of collagen XVIII and MMP-20 in developing teeth and odontogenic tumors. Matrix Biol. 2004, 23, 153-161. [CrossRef] [PubMed]

34. Tannure, P.N.; Küchler, E.C.; Lips, A.; Costa, M.C.; Luiz, R.R.; Granjeiro, J.M.; Vieira, A.R. Genetic variation in MMP20 contributes to higher caries experience. J. Dent. 2012, 40, 381-386. [CrossRef] [PubMed]

35. Antunes, L.A.; Antunes, L.S.; Küchler, E.C.; Lopes, L.B.; Moura, A.; Bigonha, R.S.; Abreu, F.V.; Granjeiro, J.M.; Amorim, L.M.F.; Paixão, I.C.N.P. Analysis of the association between polymorphisms in MMP2, MMP3, MMP9, MMP20, TIMP1, and TIMP2 genes with white spot lesions and early childhood caries. Int. J. Paediatr. Dent. 2016, 26, 310-319. [CrossRef] [PubMed]

36. Chaussain, C.; Bouazza, N.; Gasse, B.; Laffont, A.G.; Vital, S.O.; Davit-Béal, T.; Moulis, E.; Chabadel, O.; Hennequin, M.; Courson, F.; et al. Dental caries and enamelin haplotype. J. Dent. Res. 2014, 93, 360-365. [CrossRef] [PubMed]

37. McGarvey, E.L.; Leon-Verdin, M.; Killos, L.F.; Guterbock, T.; Cohn, W.F. Health disparities between Appalachian and nonAppalachian counties in Virginia USA. J. Community Health 2011, 36, 348-356. [CrossRef]

38. Vieira, A.R.; Hilands, K.M.; Braun, T.W. Saving more teeth-A case for personalized care. J. Pers. Med. 2015, 5, 30-35. [CrossRef]

39. Vieira, A.R.; McHenry, T.G.; Daack-Hirsch, S.; Murray, J.C.; Marazita, M.L. Candidate gene/loci studies in cleft lip/palate and dental anomalies finds novel susceptibility genes for clefts. Genet. Med. 2008, 10, 668-674. [CrossRef]

40. Cirulli, N.; Cantore, S.; Ballini, A.; Perillo, L.; Giannico, O.V.; Tafuri, S.; De Vito, D. Prevalence of caries and dental mal-occluisons in the apulian paediatric population: An epidemiological study. Eur. J. Paediatr. Dent. 2019, 20, 100-104. [CrossRef]

41. Cantore, S.; Mirgaldi, R.; Ballini, A.; Coscia, M.F.; Scacco, S.; Papa, F.; Inchingolo, F.; Dipalma, G.; De Vito, D. Cytokine gene polymorphisms associate with microbiogical agents in periodontal disease: Our experience. Int. J. Med Sci. 2014, 11, 674-679. [CrossRef] [PubMed]

42. Ballini, A.; Dipalma, G.; Isacco, C.G.; Boccellino, M.; Di Domenico, M.; Santacroce, L.; Nguyễn, K.C.D.; Scacco, S.; Calvani, M.; Boddi, A.; et al. Oral microbiota and immune system crosstalk: A translational research. Biology 2020, 9, 131. [CrossRef] [PubMed]

43. Inchingolo, F.; Martelli, F.S.; Isacco, C.G.; Borsani, E.; Cantore, S.; Corcioli, F.; Boddi, A.; Nguyễn, K.C.D.; De Vito, D.; Aityan, S.K.; et al. Chronic periodontitis and immunity, towards the implementation of a personalized medicine: A translational research on gene single nucleotide polymorphisms (SNPs) linked to chronic oral dysbiosis in 96 Caucasian patients. Biomedicines 2020, 8, 115. [CrossRef] [PubMed] 